\title{
LEGAL ASPECT OF ELECTRONIC MEDICAL RECORDS
}

\author{
Edi Wahjuni and Nuzulia Kumala Sari \\ Law Faculty of Universitas Jember, Indonesia \\ E-mail: wahjuniedi@yahoo.co.id
}

\begin{abstract}
Electronic medical records are needed in health care facilities for the hospital's complete, accurate and real time data requirement to improve an optimum, efficient and integrated health care. Electronic documents can be used as legal evidence based on Article 5 paragraphs (1) and (2) of Law Number 11 Year 2008 on Electronic Information and Transactions stating that electronic documents are legal evidence that is lawful and they are the expansion of legal evidence. Electronic documents are considered valid if the system is in accordance with the provision of Article 5 paragraph (3) of Law Number 11 Year 2008 on Electronic Information and Transactions.
\end{abstract}

Keywords: evidence, electronic and medical records

\begin{abstract}
Abstrak
Rekam medis elektronik diperlukan dalam fasilitas pelayanan kesehatan karena rumah sakit memerlukan data yang lengkap, akurat dan realtime, guna meningkatkan kualitas pelayanan kesehatan yang optimal, efisien dan terpadu. Dokumen elektronik dapat digunakan sebagai alat bukti hukum berdasarkan Pasal 5 ayat (1) dan (2) Undang-Undang Nomor 11 Tahun 2008 tentang Informasi dan Transaksi Elektronik menyatakan dokumen elektronik merupakan alat bukti hukum yang sah dan dokumen elektronik merupakan perluasan alat bukti yang sah. Dokumen elektronik dinyatakan sah apabila menggunakan sistem elektronik yang sesuai ketentuan Pasal 5 ayat (3) Undang-Undang Nomor 11 Tahun 2008 tentang Informasi dan Transaksi Elektronik.
\end{abstract}

Kata Kunci: alat bukti, elektronik dan rekam medis

\section{Introduction}

Globalization increases information demand in all sectors of life including health services. Consequently, it forces health services to improve the quality of information through enhancing the medical records quality. ${ }^{1}$

Medical records have very broad meaning, not limited to recording activity. Medical records is defined as an organizing system starting from recording, saving, issuing medical record documents and data analysis. Looking at the complexity of medical record management, it is the time for traditional (written) medical re-

Dian Mawarni and Ratna Dwi Wulandari, "Identification of the Fulfilment of Medical Record Incompleteness in The Inpatient of Muhammadiyah Hospital Lamongan", Jurnal Administrasi Kesehatan Indonesia, Vol. 1 No. 2, April-June 2013, p. 192. cord management to transform into electronic records. ${ }^{2}$

Electronic medical records are the adoption of information and communication technology development in health services. Basically, electronic medical records are not so different from the printed ones. The difference is on the media where medical records are displayed. The printed medical records are displayed on paper meanwhile the electronic ones are in the form of electronic/paperless document.

The legal issue of electronic medical records is on the authentication. Electronic information has not been accommodated in Indonesian procedural law system. Juridically, an activity via electronic system cannot be approached by parameter and qualification of con-

2 Wimmie Handiwidjojo, "Rekam Medis Elektronik", Jurnal Eksplorasi Karya Sistem Informasi dan Sains, Vol. 2 No. 1 May 2009, p. 35. 
ventional law. Electronic medical records are in the forms of electronic documents, written authentication, only in form of writing such as original letter and/or authentic deed. ${ }^{3}$

Electronic medical records are not written documents; however, the issuance of Law Number 11 Year 2008 on Electronic Information and Transactions brings the legal implication regarding position assurance of electronic medical records as legal evidence. Law Number 11 Year 2008 on Electronic Information and Transactions gives the influence to legal protection for stakeholders of electronic medical records user.

Legal protection is a depiction of legal function in which law can provide justice, orderliness, assurance, benefit, and peace. Law protection relates to several things such as legal relationship between patients and health workers, rights and obligations of all parties with their accountability as well as law enforcement aspect. ${ }^{4}$

Medical records are document evidence on service process provided by the doctors to the patients. Electronic medical record system can serve complete, fast, correct, and integrated data. For patients and their families, electronic medical records give the right of valid, clear, and honest information regarding the given health services. For health workers, electronic medical records support clinical decision making and increase patients' safety.

Data accuracy of electronic medical records provides society legal protection from exploitative medical practices which do not fulfill medical ethics. It also allows for assurance and legal protection to doctors from society's excessive claims. ${ }^{5}$

Information and communication technology development somehow urges several hos-

3 Nabil Atta Samandari, et al., "Kekuatan Pembuktian Rekam Medis Konvensional dan Elektronik", SOEPRA Jurnal Hukum Kesehatan, Vol. 2 No. 2, 2016, p. 154.

4 Ni Luh Gede Yogi Arthani and Made Emy Andayani Citra, "Perlindungan Hukum bagi Pasien Selaku Konsumen Jasa Pelayanan Kesehatan yang Mengalami Malpraktek", Jurnal Advokasi, Vol. 3 No. 2, 2013, p. 121.

5 Hargianti Dini Iswandari, "Legal Aspect of Medical Practice: Review Based on Medical Practice Act No. 9/2004", Jurnal Manajemen Pelayanan Kesehatan, Vol. 09 No. 02, June 2006, p. 52. pitals to make use of electronic medical records. The problems examined in this article are first, whether electronic medical records are needed by health care facilities or not; and second, whether electronic information and/or electronic documents can be used as legal evidence or not.

\section{Discussion}

\section{Electronic Medical Records Required by Health Care Facilities}

Health development is aimed at raising awareness, comfort and healthy life for everyone in order to realize the optimal health quality as one of the elements of general welfare as mandated in the preamble of the 1945 Constitution of the Republic of Indonesia. One of the efforts to realize the health quality is through the implementation of medical records in order to improve health service quality that is optimal, effective and efficient. Medical records are very essential since they affect the process of service performed by health professionals and the service quality provided by hospital. ${ }^{6}$

Article 1 paragraph (1) of the Regulation of Health Minister Number 269/MENKES/PER/III/ 2008 on Medical Records defines it as file containing records and documents concerning patients' identity, examination, treatment, action and other services given to the patients. Medical records are a summary of the complete information about the past, present and even future process of medical services. ${ }^{7}$

Medical records are one of the written evidences of the service process provided by doctors and dentists. Medical records contain patients' clinical data during the process of diagnosis and treatment. Every medical service must provide complete and accurate medical records for each patient and every doctor and

6 Izha Sukma Rahmadhani, "Faktor Penyebab Ketidaklengkapan Dokumen Rekam Medis Pasien Rawat Inap Dalam Batas Waktu Pelengkapan di Rumah Sakit Umum Daerah Dr. Moewardi Surakarta", Jurnal Kesehatan, Vol. II No. 2, October 2008, p. 82.

7 Suzeth Agustien Simbolon, "Kajian Yuridis terhadap Kedudukan Rekam Medis Elektronik dalam Pembuktian Perkara Pidana Malpraktek oleh Dokter", Jurnal Lex Crimen, Vol. IV No. 6, Agustus 2015, p. 152. 
dentist is required to complete the medical records correctly, completely and real time. ${ }^{8}$

Conventional Medical recording system so far has some weaknesses. Patients' medical record data are only stored locally in the place where the patients undergo medical examination and treatment. It is impossible to do direct exchange of data in different places. ${ }^{9}$ Hence, it is necessary to develop medical records that can provide quick, precise and integrated data.

Hospital is a complex health institution that requires a good information system in carrying out its activities. Medical records are the essential requirement for patient data for diagnosis and therapy; however, the implementation of medical records is often not completely filled and on time. ${ }^{10}$

The use of electronic medical records has potential benefits for health care facilities. One of the perceived benefits after implementing electronic medical records is improving the completeness of medical records in the hospital. It is also beneficial for patients as well as health professionals since it improves efficiency in the process of health care. Besides, for administrative officers, the use of electronic medical records can facilitate the retrieval of patient information. Therefore, the officers are easy to access patient information. Doctors and health professionals are also benefitted in performing health services for their ease in accessing patient information. As a result, it helps related parties in clinical decision making such as diagnosis, treatment, avoidance of allergic reactions and duplication of drugs. From the efficiency aspect, the use of electronic medical records provides several impacts which decrease operational cost and increase income in health

8 Syahrul Machmud, 2012, Penegakan Hukum dan Perlindungan Hukum Bagi Dokter Yang Diduga Melakukan Medikal Malpraktek, Bandung: Karya Putra Darmawati, p. 220.

9 Joko Lianto Buliali, dkk, "Sistem Pencatatan Informasi Medis Berbasis Teknologi Microsoft.Net", Jurnal Informatika, Vol. 3 No. 1, June 2007, p. 98.

10 Khasib Mabrur Ridho, dkk, "Analysis of Factors Affecting Compliance With Medical Record Completion In Hospital Dental and Oral Health Education UMY". Jurnal Medicoeticolegal dan Manajemen Rumah Sakit (JMMR), Vol. 2 No. 2 2013, p. 2. service facility. ${ }^{11}$ Through electronic medical records, the hospitals will get complete, accurate and real time data in order to improve optimum, efficient and integrated service quality.

\section{Electronic Information and/or Documents as Legal Evidence}

Medical records can be used as an evidence in law enforcement process, medical ethics and dicipline. The role of medical records in health service above and the role of doctor in doing recording are not separated, meaning that the doctor or the dentist who does recording must be responsible for the patient condition by looking at written or electronic records. If malpractice happens, the doctor must take his responsibility. ${ }^{12}$

Article 2 paragraph (1) of the Regulation of Health Minister Number 269/MENKES/PER/III/ 2008 on Medical Records has explained that there are two kinds of medical records, which are written medical records and electronic medical records. According to Nabil Atta Samandari et al., the strength difference of authentication is that electronic medical records cannot fulfill the requirements of written evidence as it is regulated in Book 4 of Civil Code Procedures (KUHPer) of Authentication and Expiration, The Second Chapter about Authentication with Writing and Article 184 paragraph (1) letters C and d, as well as Articles 187 and 188 paragraph (2) letter $b$ of Criminal Code Procedures (KUH AP). It means that conventional medical records can be used as the authentic written evidence meanwhile the electronic medical records cannot. The difference occurs since both KUHPer and KUHAP only have written authentication strength, which are only in the form of writing such as original letter and/or authentic deed. ${ }^{13}$

Medical records refer to Law on Medical Practice and The Regulation of Health Minister

11 Feby Erawantini, “Rekam Medis Elektronik: Telaah Manfaat dalam Konteks Pelayanan Kesehatan Dasar", Jurnal FIKI, Vol. 1 No. 1, 2013, p. 1.

12 CecepTriwibowo, 2014, Etika dan Hukum Kesehatan, Yogyakarta: Nuha Medika, p. 35.

13 Nabil Atta Samandari, et al., "Kekuatan Pembuktian Rekam Medis Konvensional dan Elektronik", SOEPRA Jurnal Hukum Kesehatan, Vol. 2 No. 2, 2016, p. 154. 
on Medical Records. The issuance of Law on Electronic Information and Transactions causes the use of electronic documents have legal basis.

Article 1 paragraph (4) of Law on Electronic Information and Transactions mentioned that electronic documents are electronic information created in the forms of analogue, digital, electromagnetic, optical or other same kinds which can be seen, presented and/or heard through electronic system. Electronic documents are not written document; however, based on Article 5 paragraph (1) of Law Number 11 Year 2008 on Electronic Information and Transactions, electronic information and/or electronic documents are valid legal evidence. This article is the extension of the valid evidence in accordance with valid procedural law in Indonesia.

In general explanation of Law Number 11 Year 2008 of Electronic Information and Transactions, there is electronic document which is equivalent to the document created on paper. Of course there is requirement to validate the electronic document. It must use the electronic system in accordance with the provision regulated in Article 5 paragraph (3) of Law Number 11 Year 2008 on Electronic Information and Transactions.

Article 16 paragraph (1) of Law Number 11 Year 2008 on Electronic Information and Transactions stated that the implementation of electronic system is required to operate electronic system which meets the minimum requirements as follows: first, the system is able to redisplay full electronic information and/or electronic documents; second, it can protect the availability, the integrity, the authenticity, the confidentiality, and the accessibility of the electronic system; third, it can operate based on the implementation procedure of electronic system; fourth, it is facilitated by the procedure with understandable language, information or symbol; and fifth, it has sustainable mechanism in order to maintain the novelty, the clarity, and the responsibility of the procedure.

In Law Number 11 Year 2008 on Electronic Information and Transactions, electronic medi- cal records have not been set completely and in detailed. Article 2 paragraph (2) of Regula-tion of Health Minister Number 269/MENKES/PER/III/ 2008 on Medical Records stated that the implementation of electronic medical records will be further regulated in a separated regulation. Until now, there is no regulation on electronic medical records. In order to ensure the implementation of responsible electronic medical records, Article 10 paragraph (1) of Law Number 11 Year 2008 on Electronic Information and Transactions stated that every provider of electronic transactions is certified by Reliability Certification Institution. However, to the present, there is no Reliability Certification Institution.

The implementation of electronic medical records is not different from written medical records. Article 5 paragraphs (1) and (2) of Regulation of Health Minister Number 269/MENKES/PER/III/2008 on Medical Records stated that either written or electronic medical records shall be made promptly and completely after the patient receives services by each doctor or dentist in running medical practice. Article 5 paragraph (4) also pointed out that medical records shall be accompanied by the names, times and signatures of any health worker providing direct health care. In recording of medical records using electronic information technology, the obligation to sign the signature may be replaced by using a personal identification number. ${ }^{14}$

Errors in recording medical records can be overcome with correction. Article 5 paragraphs (5) and (6) of Regulation of Health $\mathrm{Mi}$ nister Number 269/MENKES/PER/III/2008 on Medical Record stated that correction can be done by revising without eliminating the corrected record and is signed by health worker. Changes in electronic medical records should not eliminate or delete the existing data. There should be a system that ensures the recording of data changes done by whom and when. The system

\footnotetext{
14 Asril Rusli, et al., 2006, Manual Rekam Medis, Jakarta:
} Konsil Kedokteran Indonesia, p. 7. 
must also ensure that data changes do not delete the previous data.

Article 8 paragraphs (1), (2) and (3) of Regulation of Health Minister Number 269/MEN KES/PER/III/2008 on Medical Records stated that the storage and destruction of medical records are for at least 5 (five) years. Nonetheless, discharge resume and medical consent are kept for at least 10 (ten) years. The advantages of electronic medical records are electronic data stored neatly and safely, there is no expired period and has a back-up data system indefinitely. Thus, it can be used for the interest of patients and hospitals.

Every doctor or dentist in performing medical practice shall keep confidentiality concerning the patient's medical history contained in the medical record. The secret may be opened only for the interest of the patient, fulfilling the request of law enforcement officers (judge of the assembly), and the patient's own request or under applicable laws and regulations. ${ }^{15}$ Confidentiality of electronic medical records is guaranteed through personal identification number.

Article 79 of Law Number 29 Year 2004 on Medical Practice explicitly regulated that any physician or dentist who intentionally does not make a medical record may be punished with a maximum imprisonment of 1 (one) year or a fine Rp 50.000.000,- (fifty million rupiah) at most. In addition to criminal liability, doctors and dentists who do not make medical records may also be subject to civil sanctions, as doctors and dentists do not perform what they ought to do (break promises/ wages) in the doctor's relationship with the patient. Doctors and dentists who do not make medical records in addition to legal sanctions may also be subject to disciplinary and ethical sanctions in accordance with the Medical Practice Act, KKI Regulation, Indonesian Medical Code and Indonesian Dentistry Code of Ethics. ${ }^{16}$

Basic claims filed by patients to doctors based on civil case are: first, doctor does tort

15 Ibid, p. 8.

16 Ibid, p. 9.
(Article 1239 of Burgerlijk Weboek); second, doctor does the violence against the law (Article 1365 of Burgerlijk Wetboek); third, doctor does negligence causing loss (Article 1366 of Burgerlijk Wetboek); and fourth, doctor neglects the job as the person in charge (Article 1367 paragraph (3) of Burgerlijk Wetboek).

Generally, health professionals in doing their jobs have a noble purpose. The purpose is to maintain someone's body to stay health or cure the patients. ${ }^{17}$ Hospital has the responsibility towards the losses resulting from negligence of the health workers. This matter is an implementation from respondent superior doctrine, duty to care doctrine and vicarious liability doctrine, hospital liability also corporate liability. These doctrines are in accordance with Article 46 of Law Number 44 Year 2009 on Hospital. ${ }^{18}$

\section{Closing Remarks \\ Conclusion}

Electronic medical records are necessary in health service facility to improve optimal, efficient and integrated service quality. The complexity of hospital data management is not possible to be done by written medical records. By the advantages of using electronic medical records, it is the time for hospital to start using electronic medical records. Through electronic medical records, it enables hospital to obtain complete, accurate, integrated and real time data.

Electronic documents can be used as legal evidence based on Article 5 paragraphs (1) and (2) of Law Number 11 Year 2008 on Electronic Information and Transactions which stated that electronic documents are valid legal evidence and are the extension of valid evidence. Electronic documents are considered legal if they use electronic system that is in accordance with the provision of Article 5 paragraph (3) of Law

\footnotetext{
17 Bambang Tri Bawono, "Kebijakan Hukum Pidana dalam Upaya Penanggulangan Malpraktik Profesi Medis", Jurnal Hukum, Vol. XXV No. 1 April 2011, p. 453.

18 Setya Wahyudi, "Tanggung Jawab Rumah Sakit terhadap Kerugian Akibat Kelalaian Tenaga Kesehatan dan Implikasinya", Jurnal Dinamika Hukum, Vol. 11 No. 3 September 2011, p. 505.
} 
Number 11 Year 2007 on Electronic Information and Transactions.

\section{Suggestion}

In Law on Electronic Information and Transactions, electronic medical records have not been regulated completely and in detailed. Article 2 paragraph (2) of the Regulation of Health Minister Number 269/MENKES/PER/III/ 2008 on Medical Records stated that the implementation of electronic medical records will be further regulated in a separated regulation. Government and related parties should soon arrange Regulation of Health Minister on Electronic Medical Records.

Article 10 paragraph (2) of Law Number 11 Year 2008 on Electronic Information and Transactions stated concerning the establishment of Electronic Medical Record Certification Institution. Until now, there is no Electronic Medical Record Certification Institution. Government should establish that institution very soon by arranging Government Regulation in order to ensure the implementation of responsible electronic medical records. Provision of Article 1 paragraph (11) called as Reliability Certification Institution is an independent institution which is established by recognized professional, legalized and supervised by Government with authorities in auditing and issuing reliability certificate in electronic transactions.

\section{References}

Arthani, Ni Luh Gede Yogi and Citra, Made Emy Andayani. "Perlindungan Hukum bagi Pasien Selaku Konsumen Jasa Pelayanan Kesehatan yang Mengalami Malpraktek". Jurnal Advokasi. Vol. 3 No. 2. 2013. Pp. 119-127;

Bawono, Bambang Tri. "Kebijakan Hukum Pidana dalam Upaya Penanggulangan Malpraktik Profesi Medis". Jurnal Hukum. Vol. XXV No. 1. April 2011. Pp. 453-473;

Buliali, Joko Lianto. "Sistem Pencatatan Informasi Medis Berbasis Teknologi Microsoft. Net”. Jurnal Informatika. Vol. 3 No. 1. June 2007. Pp. 97-118;

Erawantini, Feby. Et. Al. "Rekam Medis Elektronik: Telaah Manfaat dalam Konteks Pela- yanan Kesehatan Dasar". Jurnal FIKI. Vol. 1 No. 1. 2013, Pp. 1-11;

Handiwidjojo, Wimmie. "Rekam Medis Elektronik". Jurnal Eksplorasi Karya Sistem Informasi dan Sains. Vol. 2 No. 1. May 2009. Pp. 36-41;

Iswandari, Hargianti Dini. "Legal Aspect of Medical Practice: Review Based on Medical Practice Act No. 9/2004". Jurnal Manajemen Pelayanan Kesehatan. Vol. 09 No. 02. June 2006. p. 52-57;

Machmud, Syahrul. 2012. Penegakan Hukum dan Perlindungan Hukum Bagi Dokter Yang Diduga Melakukan Medikal Malpraktek. Bandung: Karya Putra Darmawati;

Mawarni, Dian and Ratna Dwi Wulandari. "Identification of The Fulfilment of Medical Record Incompleteness in The Inpatient of Muhammadiyah Hospital Lamongan". Jurnal Administrasi Kesehatan Indonesia. Vol 1 No. 2. April-June 2013. Pp. 192-199;

Rahmadhani, Izha Sukma. "Faktor Penyebab Ketidaklengkapan Dokumen Rekam Medis Pasien Rawat Inap Dalam Batas Waktu Pelengkapan di Rumah Sakit Umum Daerah Dr. Moewardi Surakarta". Jurnal Kesehatan. Vol. II No. 2. October 2008. Pp. 8288;

Ridho, Khasib Mabrur. Et.Al. "Analysis of Factors Affecting Compliance With Medical Re-cord Completion In Hospital Dental and Oral Health Education UMY". Jurnal Medicoeticolegal dan Manajemen Rumah Sakit (JMMR). Vol. 2 No. 2. 2013. Pp. 1-18;

Rusli, Asril. Et. Al. 2006. Manual Rekam Medis. Jakarta: Konsil Kedokteran Indonesia

Samandari, Nabil Atta. Et. Al. "Kekuatan Pembuktian Rekam Medis Konvensional dan Elektronik". SOEPRA Jurnal Hukum Kesehatan. Vol. 2 No. 2. 2016. Pp. 154-164;

Simbolon, Suzeth Agustien. "Kajian Yuridis terhadap Kedudukan Rekam Medis Elektronik dalam Pembuktian Perkara Pidana Malpraktek oleh Dokter". Jurnal Lex Crimen. Vol. IV No. 6. August 2015. Pp. 152-161;

Triwibowo, Cecep. 2014. Etika dan Hukum Kesehatan. Jogjakarta: Nuha Medika;

Wahyudi, Setya. "Tanggung Jawab Rumah Sakit terhadap Kerugian Akibat Kelalaian Tenaga Kesehatan dan Implikasinya". Jurnal Dinamika Hukum. Vol. 11 No. 3. September 2011. Pp. 505-521. DOI: 10.20884/1. jdh.2011.11.3.178. 